Research Article

\title{
Larval Cytotoxic and Subacute Toxicity of Gardenia ternifolia, Rourea coccinea, and Cassytha filiformis Used in Traditional Medicine of Benin (West Africa)
}

\author{
E. Agbodjento $\mathbb{D}^{1},{ }^{1}$ J. R. Klotoé $\mathbb{C},{ }^{1,2}$ T. I. Sacramento, ${ }^{3}$ T. V. Dougnon ${ }^{\mathbb{D}},{ }^{1}$ E. Déguenon, ${ }^{1}$ \\ J. Agbankpé, ${ }^{1}$ K. Fabiyi, ${ }^{1}$ P. Assogba, ${ }^{1}$ M.-P. Hounkanrin,, ${ }^{1}$ R. Akotegnon, ${ }^{1}$ T. J. Dougnon, ${ }^{1}$ \\ and J.-M. Atègbo ${ }^{4}$ \\ ${ }^{1}$ Research Unit in Applied Microbiology and Pharmacology of natural substances, Research Laboratory in Applied Biology, \\ Polytechnic School of Abomey-Calavi, University of Abomey-Calavi, 01P.O.Box 2009, Cotonou, Benin \\ ${ }^{2}$ Normal High School of Natitingou, National University of Sciences, Technology, Engineering and Mathematics, P.O. Box 72, \\ Natitingou, Benin \\ ${ }^{3}$ School of Management and Operation of Livestock Systems, National University of Agriculture, Ketou, Benin \\ ${ }^{4}$ Laboratory of Molecular Physiopathology and Toxicology, Faculty of Sciences and Techniques, University of Abomey-Calavi, \\ 01 P.O.Box 526, Cotonou, Benin
}

Correspondence should be addressed to J. R. Klotoé; jrklotoe@yahoo.fr

Received 19 August 2020; Revised 5 October 2020; Accepted 14 October 2020; Published 29 October 2020

Academic Editor: Massimo Moretti

Copyright (C) 2020 E. Agbodjento et al. This is an open access article distributed under the Creative Commons Attribution License, which permits unrestricted use, distribution, and reproduction in any medium, provided the original work is properly cited.

\begin{abstract}
The use of medicinal plants in traditional medicine is a common practice in developing countries. However, this unregulated or irrational use may pose a risk of toxicity to humans in the short and/or long term. Recent studies reported interesting ethnopharmacological, antioxidant, and phytochemical data on some medicinal plants used in the traditional treatment of male infertility in Benin. Unfortunately, very little data exist on the long-repeated dose toxicity of these medicinal plants. This study was aimed at evaluating the larval cytotoxicity and subacute toxicity of the hydroethanolic extract of Cassytha filiformis whole plant, Gardenia ternifolia roots, and Rourea coccinea leaves. The subacute toxicity of these plants was evaluated in male Wistar albino rats at three different doses $(200,400$, and $800 \mathrm{mg} / \mathrm{kg}$ ) according to the OECD 407 guidelines. Hematological and biochemical examinations and the histological study of the liver and kidneys were carried out. Larval cytotoxicity was assessed by the sensitivity of Artemia salina larvae to different concentrations of the studied plants extracts. The mean lethal concentration (LC $\left.{ }_{50}\right)$ was determined by the probit method. Subacute toxicity data indicated that there was no mortality or structural alterations of the liver and kidneys in the lot of treated animals. However, significant alterations in certain hematological and biochemical parameters (hematocrit, ASAT, and uremia) were noted. These abnormalities were observed in the lot of rats treated with Rourea coccinea and Cassytha filiformis extracts. Larval cytotoxicity data indicate that the studied plants extracts are not cytotoxic $\left(\mathrm{LC}_{50}>0.1 \mathrm{mg} / \mathrm{mL}\right)$. These data suggest that the use in traditional medicine of studied plants at high doses and repeated over a long period of time requires special attention.
\end{abstract}

\section{Introduction}

Traditional medicine has an important place in primary healthcare for people throughout the world. According to the WHO, more than $80 \%$ of the African and Western population use this medicine for a multitude of reasons and for their well-being [1]. This medical practice based on the use of medicinal plants is an ancestral tradition handed down from generation to generation $[2,3]$. The population uses remedies without guaranteeing the safety of the medicinal plants that compose them. In the literature, reports have mentioned that poorly matched combinations of plants present toxicity risks $[4,5]$. These data suggest that the toxicological characterization of medicinal plants is of 
paramount importance for safe use in phytotherapy. Reports in the literature have demonstrated the short-, medium-, and long-term toxic effects of medicinal plants $[6,7]$.

Africa is known for the richness of its flora, which is conducive to scientific studies for a better valuation of these natural resources. Benin has an interesting ethnobotanical potential. Akoègninou et al. [8] estimated the Beninese flora at more than 2807 plant species. Gardenia ternifolia (G. ternifolia), Cassytha filiformis (C. filiformis), and Rourea coccinea ( $R$. coccinea) are three plants of Beninese flora used in the traditional treatment of male infertility [9]. Recent studies reported the antioxidant potential and the richness of these three plants in polyphenols and flavonoids, which often are responsible for their medicinal properties [10]. In the African and Western pharmacopoeias, G. ternifolia, $C$. filiformis, and $R$. coccinea have numerous ethnopharmacological applications.

In Togo, G. ternifolia leaves are traditionally used in the treatment of hypertension $[11,12]$ and diabetes [13]. In RD Congo, the same leaves of the plant are indicated in the management of sickle cell disease [14], cancer [15], and hemorrhoids [16]. The roots and fruits of G. ternifolia are used, respectively, in Ethiopia [17] and Sudan [18] in the treatment of malaria. In the Guinean pharmacopoeia, all parts of G. ternifolia are known to have powerful antibiotic, hypotensive, and antidiabetic properties $[19,20]$. In Nigeria, G. ternifolia leaves are used in the treatment of liver necrosis [21]. In Senegal, it has been reported that the leaves of the plant are used to treat diarrhea [22], while its roots are used to treat tooth decay, hemorrhoids, leprosy, and rheumatism [23]. These therapeutic virtues of G. ternifolia are attributed to alkaloids, anthocyanins, flavonoids, phenols, saponins, tannins, steroids, and terpenoids identified in different parts of the plant $[17,24]$.

$R$. coccinea is a medicinal plant whose therapeutic virtues are widely recognized in West Africa. In Nigeria, the leaves are used in the treatment of diabetes [25], fever [26], diarrhea [27], and sexually transmitted infections [28]. In Benin, the plant is indicated in the treatment of malaria, male and female infertility, and sexual asthenia $[8,29]$. In Togo, the different medicinal uses of the leaves concern dysmenorrhea, hypertension, primary and secondary sterility, tachycardia, rheumatism, hemorrhages, gonorrhea, and mucus [30, 31]. The roots of $R$. coccinea are used in the treatment of anemia, sexual asthenia, and male and female sterility [30]. In Côte d'Ivoire, all parts of the whole plant are used in the treatment of sore throats and muscular and rheumatic pain [32]. These therapeutic uses of Rourea coccinea could be explained by the effect of saponins, tannins, steroids, reducing sugar, glycosides, flavonoids, anthraquinone, and alkaloids identified as secondary metabolites in different parts of the plant $[28,33,34]$.

As for C. filiformis, its therapeutic virtues are recognized in several pharmacopoeias throughout the world. In Polynesia, several people use C. filiformis in the treatment of cancers [35]. In northern Nigeria, C. filiformis is used in the treatment of diabetes mellitus [36]. In Benin, the plant is indicated in the treatment of gastric ulcers, haemorrhoids, and cough [37]. Secondary metabolites such as flavonoids, phenols, alkaloids, tannins, steroids, and saponins identified in different raw extracts of Cassytha filiformis would be responsible for these medicinal properties of the plant $[38,39]$.

The above evidence attests to the importance of $G$. ternifolia, C. filiformis, and $R$. coccinea in traditional African and Western medicine. Unfortunately, despite this frequency of use of these plants for health purposes, it must be noted that rare or nonexistent toxicity tests have explored their safety following long repeated use at different doses. Literature data indicate that the toxicity of medicinal plants can also be established in long-repeated small doses [40]. In addition, in traditional medicine, the management of pathologies most often requires the use of medicinal potions over a long period of time.

This study was initiated to fill this gap in the scarcity of scientific data on the repeated dose toxicity of selected plants. It aimed to evaluate larval cytotoxicity and subacute toxicity of G. ternifolia roots, C. filiformis whole plant, and $R$. coccinea leaves in rats to predict its safety in human use. Rats are recommended lower level of animals for toxicity studies to extrapolate to human biology according to the Organization for Economic Cooperation and Development (OECD) safety study guidelines [41, 42]. The finding of the study could also help to guide optimization and validation of the traditional use of these medicinal plants.

\section{Materials and Methods}

\subsection{Study Material}

2.1.1. Plant Material. Plant materials used were constituted of $G$. ternifolia roots, $C$. filiformis whole plant, and $R$. coccinea leaves. These plant organs were collected in March 2019 in the municipality of Za-Kpota and Djidja (Zou department, southern Benin) and certified at the Benin National Herbarium under the voucher number YH261/ HNB for Rourea coccinea, YH262/HNB for Cassytha filiformis, and YH263/HNB for Gardenia ternifolia. The harvest time of these plants studied was chosen based on the foliage time of each plant. In addition, it is during these periods that the traditional healers collect these plant samples for use in Beninese pharmacopeia.

2.1.2. Animal Material. The animal materials were constituted by Artemia salina eggs (ARTEMIO JBL D-67141 Gmbh Neuhofem) and male Wistar rats. Artemia salina' eggs (ARTEMIO JBL D-67141 Gmbh Neuhofem), acquired from the Applied Hydrobiology's Laboratory of Agricultural Sciences' Faculty at University of Abomey-Calavi (UAC, Benin), were used for the larval cytotoxicity test. Male Wistar albino rats aged at least three months with a body weight between $150 \mathrm{~g}$ and $200 \mathrm{~g}$ were used as the animal material for the subacute toxicity test. These animals have been acquired at the animal farm of the Institute of Applied Biomedical Sciences of the University of Abomey-Calavi of Benin. They have been housed in cages covered with wood chips and acclimatized for 2 weeks before experiment at the animal farm of the Research Unit in Applied Microbiology and 
Pharmacology of natural substances (URMAPha). The rats had free access to water and food. Animal Research Review Panel and Animal Welfare Unit regulations of temperature and lighting systems were maintained with a room temperature of $20-26^{\circ} \mathrm{C}$ and regular light cycles of 12 hours light/dark. All methods and protocols used in this study were observed following established public health guidelines "Guide for Care and Use of Laboratory Animals."

2.2. Ethical Approval. This study is part of a thesis. The committee of the "Doctoral School Life and Earth Science (ED-SVT)" of the University of Abomey-Calavi (UACBenin) under the number 10185509 has authorized this study.

\subsection{Methods of Study}

2.3.1. Production of Plant Extracts. R. coccinea leaves, C. filiformis whole plant, and G. ternifolia roots collected were washed thoroughly with tap water to remove any form of dirt and dried in the shade at room temperature at the Research Unit in Applied Microbiology and Pharmacology of natural substances (URMAPha). They were then powdered with an electric mill. From this powder, a hydroethanolic extraction was carried out according to the methodology described by Klotoé et al. [10]. Fifty (50) grams of powder were macerated in $500 \mathrm{~mL}$ of the mixed solvent with equal volume of distilled water and $96 \%$ ethanol. The mixture was continuously stirred for 72 hours at room temperature. The homogenate obtained has been filtered three times on hydrophilic cotton and once on Wittman paper No. 1. The filtrate obtained has been evaporated at the temperature of $40^{\circ} \mathrm{C}$ in an oven until a dry mass that represents the extract. The extract obtained has been weighed and used to evaluate the extraction yield (EY) and then kept in the refrigerator at $4^{\circ} \mathrm{C}$. The following formula was used:

$$
\mathrm{EY}=\frac{\text { Mass of the extract after evaporation of the solvent }}{\text { Mass of the powder of the plant species used for extraction }} \times 100
$$

2.3.2. Larval Cytotoxicity Test. The cytotoxic effect of the studied plants hydroethanolic extract was evaluated on brine shrimp larvae. This is a preliminary nonclinical toxicity test performed according to the method described by Dougnon et al. [43]. Artemia salina larvae were obtained by hatching $10 \mathrm{mg}$ of Artemia salina eggs under continuous agitation in $1 \mathrm{~L}$ of seawater for $48 \mathrm{~h}$. Order stock extract solution's 2 dilution series with a concentration of $20 \mathrm{mg} / \mathrm{mL}$ were carried out in order to have an increasing scale concentration. $1 \mathrm{~mL}$ of each diluted solutions was added to $1 \mathrm{~mL}$ of sea water containing 16 live larvae. A control solution without the extract was prepared under same conditions. All solutions were incubated under agitation for 24 hours. Counting dead larvae number in each solution under an optical microscope produced a representative curve of the number of surviving larvae versus the concentration of the extract. The data (concentration-response) were logtransformed, and the $\mathrm{LC}_{50}$ (mean lethal concentrations) was determined. To assess the larval toxicity of the extract, the correlation grid associating the degree of toxicity with $\mathrm{LC}_{50}$ proposed by Mousseux was used [44]. According to this grid, if the $\mathrm{LC}_{50}$ value is greater than $0.1 \mathrm{mg} / \mathrm{mL}$, the extract is declared nontoxic. If this value is between 0.1 and $0.5 \mathrm{mg} /$ $\mathrm{mL}$, the extract is weakly toxic, and if the $\mathrm{LC}_{50}$ is less than $0.5 \mathrm{mg} / \mathrm{mL}$, the extract is toxic.

2.3.3. Subacute Toxicity Test. This study was conducted according to the OECD 407 guidelines [41], a method by subacute toxicity class. Forty (40) male Wistar albino rats divided by weight into ten (10) lots (9 test lots and one control lot) of four rats each were used in this study. The animals in the test lots were treated at the same time for a period of 28 days by esophageal gavage using three gradual doses $(200,400$, and $800 \mathrm{mg} / \mathrm{kg})$ selected from the active pharmacological dose. Previous scientific investigations on these medicinal plants agree on $200 \mathrm{mg} / \mathrm{kg}$ as their pharmacologically active dose $[31,45,46]$. The control lot is treated with distilled water under same conditions. Animals in each lot were individually marked with permanent markers.
Lot 1: distilled water, $1 \mathrm{~mL} / 100 \mathrm{~g}$ (control)
Lot 2: G. ternifolia, $200 \mathrm{mg} / \mathrm{kg}$
Lot 3: G. ternifolia, $400 \mathrm{mg} / \mathrm{kg}$
Lot 4: G. ternifolia, $800 \mathrm{mg} / \mathrm{kg}$
Lot 5: C. filiformis, $200 \mathrm{mg} / \mathrm{kg}$
Lot 6: C. filiformis, $400 \mathrm{mg} / \mathrm{kg}$
Lot 7: C. filiformis, $800 \mathrm{mg} / \mathrm{kg}$
Lot 8: $R$. coccinea, $200 \mathrm{mg} / \mathrm{kg}$
Lot 9: $R$. coccinea, $400 \mathrm{mg} / \mathrm{kg}$
Lot 10: R. coccinea, $800 \mathrm{mg} / \mathrm{kg}$

During the experiment, the animals were weighed every seven days (day 0 , day 7 , day 14 , day 21 , and day 28 ), followed, and observed individually twice a day (morning and evening). A data collection sheet was prepared for each rat to collect possible signs of toxicity (changes in skin, hair, edema, walking back, respiratory difficulties, morbidity, and mortality). At the end of treatment, rats were deprived of food the last night before sampling. Blood samples (day 0 and day 28) were performed by puncture at the retroorbital sinus for all animals under ether anesthesia. The blood sample is recovered from two types of tubes, one containing 
EDTA and one dry without anticoagulant. The EDTA tube sample is intended for hematological analysis. Dry tubes were centrifuged at $4000 \mathrm{rpm}$ for 10 minutes, and the serum obtained is kept at $-20^{\circ} \mathrm{C}$ for biochemical parameter analysis. After sampling, two animals in each lot were sacrificed under anesthesia with ether for the collection of organs such as the liver and kidney. These organs were rinsed with a $0.9 \%$ saline water and fixed in $10 \%$ buffered formaldehyde.

(1) Hematological Examinations. These examinations were performed using the SYSMEX KX $21 \mathrm{~N}$ automaton using the method used by Sodipo et al. [47]. These examinations included red and white blood cell counts, hemoglobin level, hematocrit, mean globular volume (MGV), mean corpuscular hemoglobin content $(\mathrm{MCH})$, and determination of mean corpuscular hemoglobin concentration (MCHC).

(2) Biochemical Examinations. The biochemical tests were performed at the Research Unit in Applied Microbiology and Pharmacology of natural substances (URMAPha). This consisted to the determination of urea, creatinine, aspartate aminotransferase (ASAT), and alanine aminotransferase (ALAT).

(3) Histological Examinations. Histological sections of the liver and kidneys were performed at the Histopathology Laboratory of the Institute of Applied Biomedical Sciences (ISBA) of the University of Abomey-Calavi. The pathomorphological study consisted of hematoxylin-eosin staining of thin sections of $5 \mu \mathrm{m}$ thicknesses. It is routine staining after which the nuclei, stained by hematoxylin, appear dark blue and the cytoplasm, stained by eosin, appear pink. The microscopic observation of these sections was carried out with the ZEISS camera microscope at different magnifications, so that only the most representative photographs were selected.

2.3.4. Data Analysis. The obtained data were subjected to statistical analysis using the SPSS 26.0 and Graph Pad Prism 7 software. Quantitative variables were presented as mean and standard deviation. Qualitative variables were presented in percentages. The probit analysis was used for $\mathrm{LC}_{50}$ determination. The student test was used to compare the values of the different biochemical, hematological, and weight gain parameters of the treated animals with those of the control lot. The significance threshold was set at $5 \%$.

\section{Results}

The data are obtained in this study related to the extraction yield, larval cytotoxicity, and different parameters of subacute toxicity.

3.1. Extraction Yield. The extraction yield obtained for hydroethanolic extraction for the studied plants is shown in Figure 1. From this figure, it emerges that the hydroethanolic extract of $R$. coccinea gave a better yield than the other two plant organs. The lowest yield was obtained with G. ternifolia roots.

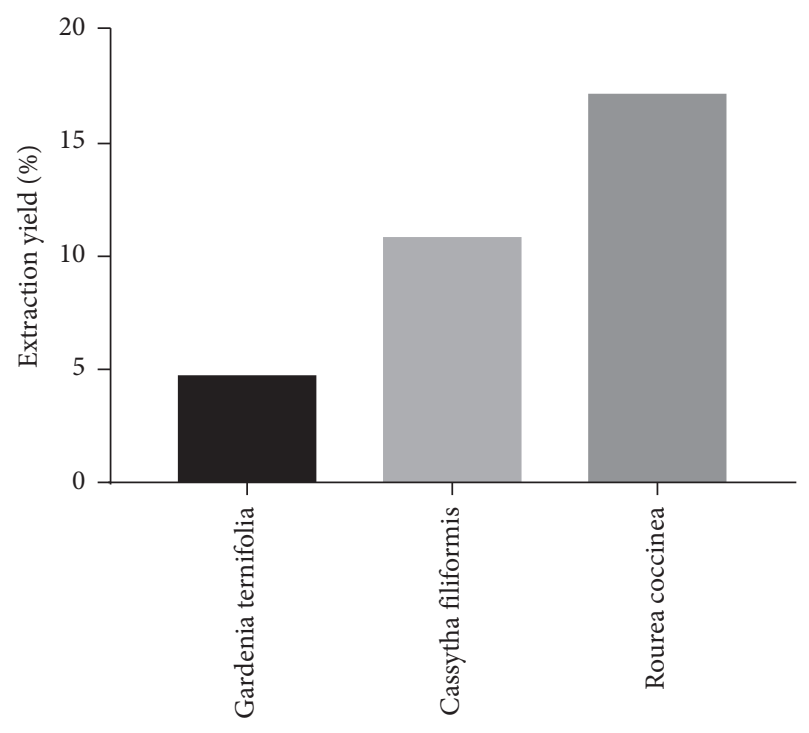

FIgURE 1: Extraction yield.

3.2. Larval Cytotoxicity. The sensitivity of Artemia salina larvae to different concentrations of the hydroethanolic extract of the plants studied is presented in Figure 2. The results show an increasing mortality of Artemia salina larvae as the concentration of extracts from the plants studied increases. The obtained $\mathrm{LC}_{50}$ was $0.203 \mathrm{mg} / \mathrm{mL}$ for C. filiformis, $0.166 \mathrm{mg} / \mathrm{mL}$ for $R$. coccinea, and $2.773 \mathrm{mg} / \mathrm{mL}$ for $G$. ternifolia, respectively. These $\mathrm{LC}_{50}$ values reported at the scale of Mousseux [44] suggest that at the concentrations tested, the hydroethanolic extract of the plants studied is noncytotoxic $\left(\mathrm{LC}_{50}>0.1 \mathrm{mg} / \mathrm{mL}\right)$.

\subsection{Subacute Toxicity}

3.3.1. Evolution of Animal Weight. The evolution of the weight of the animals during the experimental period is shown in Figure 3. In general, it is noted that the treatments performed have an influence on the weight growth of animals. This influence varies according to the plants studied and the period of exposure of the animals to the different plant extracts. Thus, compared to the weight change control group rats, a nonsignificant weight growth was observed throughout the experimental period for treated rats with the three doses of $G$. ternifolia $(p>0.05)$. The same situation is observed for the treated animals with $C$. filiformis. However, for $R$. coccinea, a variable influence of dose and time (treatment week) on animal weight growth was observed. Thus, at the $200 \mathrm{mg} / \mathrm{kg}$, a nonsignificant weight loss was observed after two weeks of treatment before a resumption of weight growth in the last two weeks. At doses of 400 and $800 \mathrm{mg} / \mathrm{kg}$, a nonsignificant loss of animal bodyweight was observed for treatments performed. This weight loss was significant during the last week of treatment for rats treated at $800 \mathrm{mg} / \mathrm{kg}$ dose $(p<0.05)$.

3.3.2. Effect of Plant Extracts on Hematological Parameters of Treated and Control Rats. Table 1 provides information on 


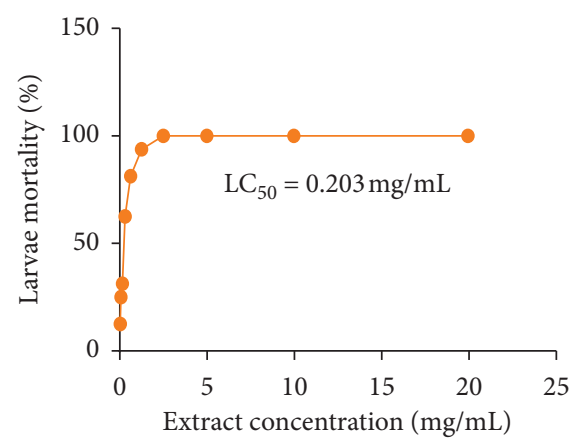

(a)

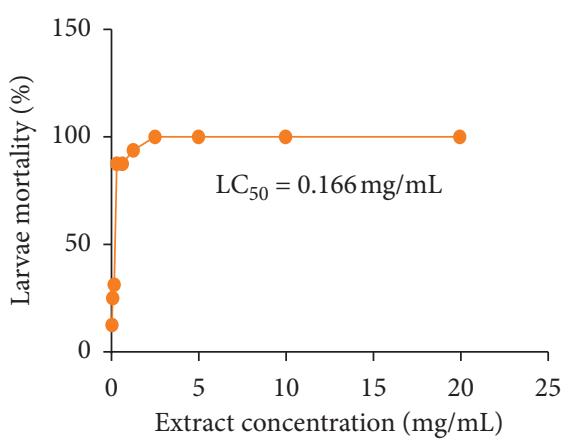

(b)

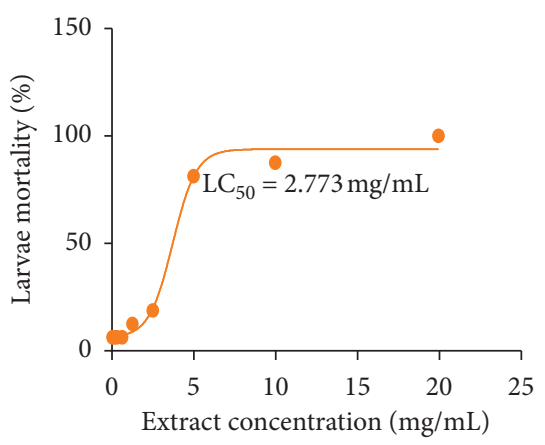

(c)

Figure 2: Sensitivity of Artemia salina larvae to the studied plants. (a) Cassytha filiformis; (b) Rourea coccinea; (c) Gardenia ternifolia; LC ${ }_{50}$, lethal mean concentration.

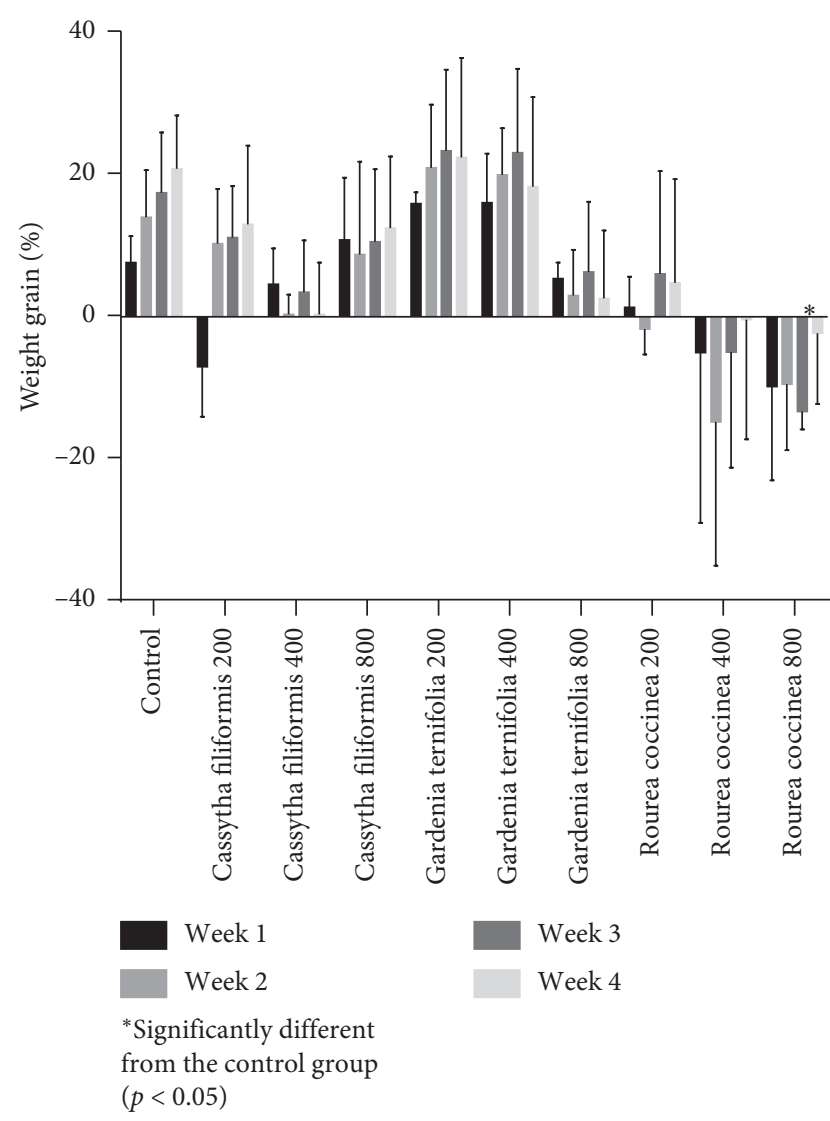

FIGURE 3: Evolution of animal bodyweight during the experimental period.

the effect of the studied plants extracts on the hematological parameters of the animals of the different lots. The analysis of this table shows a significant reduction in the hematocrit level for animals treated with extracts of $C$. filiformis and $R$. coccinea compared to untreated rats for the erythrocyte data $(p<0.05)$. In addition, a nonsignificant dose-dependent reduction in the red blood cell count, mean cell volume, hemoglobin level, and mean corpuscular hemoglobin concentration was also noted for the treated rats with $R$. coccinea $(p>0.05)$. For $C$. filiformis, a nonsignificant reduction in the mean blood volume and mean body hemoglobin content accompanies the significant reduction in the hematocrit. These data suggest microcytic hypochromic anemia in Wistar rats treated with $R$. coccinea and C. filiformis. For G. ternifolia, no significant effect on hematological parameters is reported for the studied doses.

3.3.3. Effect of the Studied Plants Extracts on Biochemical Parameters. Renal parameters (urea and creatinine) were examined to explore renal function. Alanine aminotransferase (ALAT) and aspartate aminotransferase (ASAT) were considered in the exploration of the liver function (Table 2). Analysis of the data in this table indicates that animals treated with $400 \mathrm{mg} / \mathrm{kg}$ and $800 \mathrm{mg} / \mathrm{kg}$ of the plants studied showed a significant increase in uremia $(p<0.05)$. However, no significant influence on creatinemia of animals was noted $(p>0.05)$.

In addition, concerning to liver parameters, a significant reduction in serum ASAT was observed in animals treated with $R$. coccinea and C. filiformis particularly at doses of $400 \mathrm{mg} / \mathrm{kg}$ and $800 \mathrm{mg} / \mathrm{kg}$. However, no significant difference was noted for this parameter in rats treated with G. ternifolia. On ALAT, except the animals treated with Cassytha filiformis $200 \mathrm{mg} / \mathrm{kg}$ and Gardenia ternifolia $400 \mathrm{mg} / \mathrm{kg}$, no significant influence was noted for this hepatic parameter of animals in other lots $(p>0.05)$.

3.3.4. Histological Examination of the Liver and Kidney. Figure 4 shows the liver histology of treated and untreated animals. From this figure, it appears that the hepatic parenchyma of treated rats has the same appearance as that of control rats. Hepatocytes (arrows) have a normal appearance and are arranged in cords separated by sinusoids $(s)$. These sinusoids are arranged around the centrolobular vein $(V)$. Figure 5 shows the renal histology of the treated animals and the control group. Analysis of the data in this figure indicates 


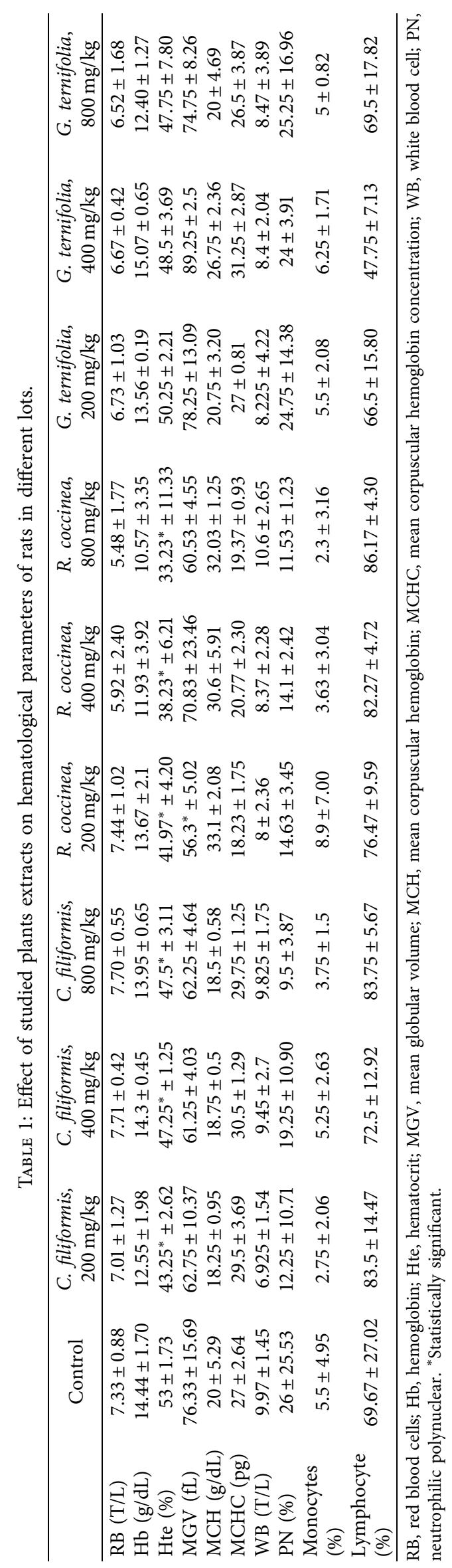


TABLE 2: Effect of studied plants extracts on biochemical parameters of rats in different lots.

\begin{tabular}{lccccc}
\hline & & Uremia $(\mathrm{g} / \mathrm{L})$ & Creatinemia $(\mathrm{mg} / \mathrm{L})$ & ASAT $(\mathrm{UI} / \mathrm{L})$ & ALAT $(\mathrm{UI} / \mathrm{L})$ \\
\hline \multirow{2}{*}{ Control } & Day 0 & $0.34 \pm 0.03$ & $7.47 \pm 0.46$ & $147.5 \pm 19.36$ & $144.5 \pm 68.22$ \\
& Day 28 & $0.36 \pm 0.04$ & $7.77 \pm 0.47$ & $154.5 \pm 17.92$ & $106.5 \pm 24.79$ \\
\hline \multirow{2}{*}{ C. filiformis, $200 \mathrm{mg} / \mathrm{kg}$} & Day 0 & $0.37 \pm 0.02$ & $6.49 \pm 0.53$ & $124.75 \pm 19.62$ & $158.25 \pm 53.24$ \\
& Day 28 & $0.43 \pm 0.05$ & $6.62 \pm 0.56$ & $65.25 \pm 57.24^{*}$ & $175.25 \pm 32.16$ \\
\hline \multirow{2}{*}{ C. filiformis, $400 \mathrm{mg} / \mathrm{kg}$} & Day 0 & $0.39 \pm 0.05$ & $7.40 \pm 1.06$ & $141.25 \pm 23.93$ & $146.12 \pm 70.45$ \\
& Day 28 & $0.51 \pm 0.03^{*}$ & $7.91 \pm 1.52$ & $42.5 \pm 23.06^{*}$ & $155 \pm 40.50$ \\
\hline \multirow{2}{*}{ C. filiformis, $800 \mathrm{mg} / \mathrm{kg}$} & Day 0 & $0.37 \pm 0.03$ & $6.83 \pm 1.58$ & $132 \pm 9.09$ & $104 \pm 23.17$ \\
& Day 28 & $0.55 \pm 0.10^{*}$ & $7.125 \pm 1.84$ & $23.25 \pm 16.46^{*}$ & $110.75 \pm 29.85$ \\
\hline \multirow{2}{*}{ R. coccinea, $200 \mathrm{mg} / \mathrm{kg}$} & Day 0 & $0.39 \pm 0.01$ & $6.42 \pm 0.29$ & $134.67 \pm 11.37$ & $123 \pm 14.11$ \\
& Day 28 & $0.44 \pm 0.06$ & $6.61 \pm 0.32$ & $15.67 \pm 4.51^{*}$ & $144.67 \pm 41.02$ \\
\hline \multirow{2}{*}{ R. coccinea, $400 \mathrm{mg} / \mathrm{kg}$} & Day 0 & $0.38 \pm 0.03$ & $5.39 \pm 1.49$ & $146.67 \pm 17.56$ & $142.67 \pm 83.93$ \\
& Day 28 & $0.58 \pm 0.05^{*}$ & $5.47 \pm 1.51$ & $53.33 \pm 40.50^{*}$ & $177.67 \pm 64.06$ \\
\hline \multirow{2}{*}{. coccinea, $800 \mathrm{mg} / \mathrm{kg}$} & Day 0 & $0.35 \pm 0.03$ & $5.29 \pm 1.21$ & $136 \pm 5.29$ & $190.33 \pm 42.03$ \\
& Day 28 & $0.59 \pm 0.06^{*}$ & $5.51 \pm 1.39$ & $91.33 \pm 23.85^{*}$ & $196.33 \pm 26.31$ \\
\hline \multirow{2}{*}{ G. ternifolia, $200 \mathrm{mg} / \mathrm{kg}$} & Day 0 & $0.36 \pm 0.04$ & $7.46 \pm 0.48$ & $231.75 \pm 50.43$ & $126 \pm 65.79$ \\
& Day 28 & $0.43 \pm 0.03$ & $8.05 \pm 0.91$ & $235.75 \pm 52.80$ & $132 \pm 97.01$ \\
\hline \multirow{2}{*}{ G. ternifolia, $400 \mathrm{mg} / \mathrm{kg}$} & Day 0 & $0.39 \pm 0.01$ & $7.52 \pm 0.48$ & $221.5 \pm 44.22$ & $173.25 \pm 93.18$ \\
& Day 28 & $0.49 \pm 0.03^{*}$ & $7.45 \pm 0.43$ & $246 \pm 68.14$ & $131.75 \pm 120.35$ \\
\hline \multirow{2}{*}{ G. ternifolia, $800 \mathrm{mg} / \mathrm{kg}$} & Day 0 & $0.37 \pm 0.03$ & $7.8 \pm 0.79$ & $170 \pm 31.62$ & $78.25 \pm 12.34$ \\
& Day 28 & $0.60 \pm 0.10^{*}$ & $8.32 \pm 1.32$ & $170.5 \pm 40.83$ & $71 \pm 12.67$ \\
\hline
\end{tabular}

* Significantly different.

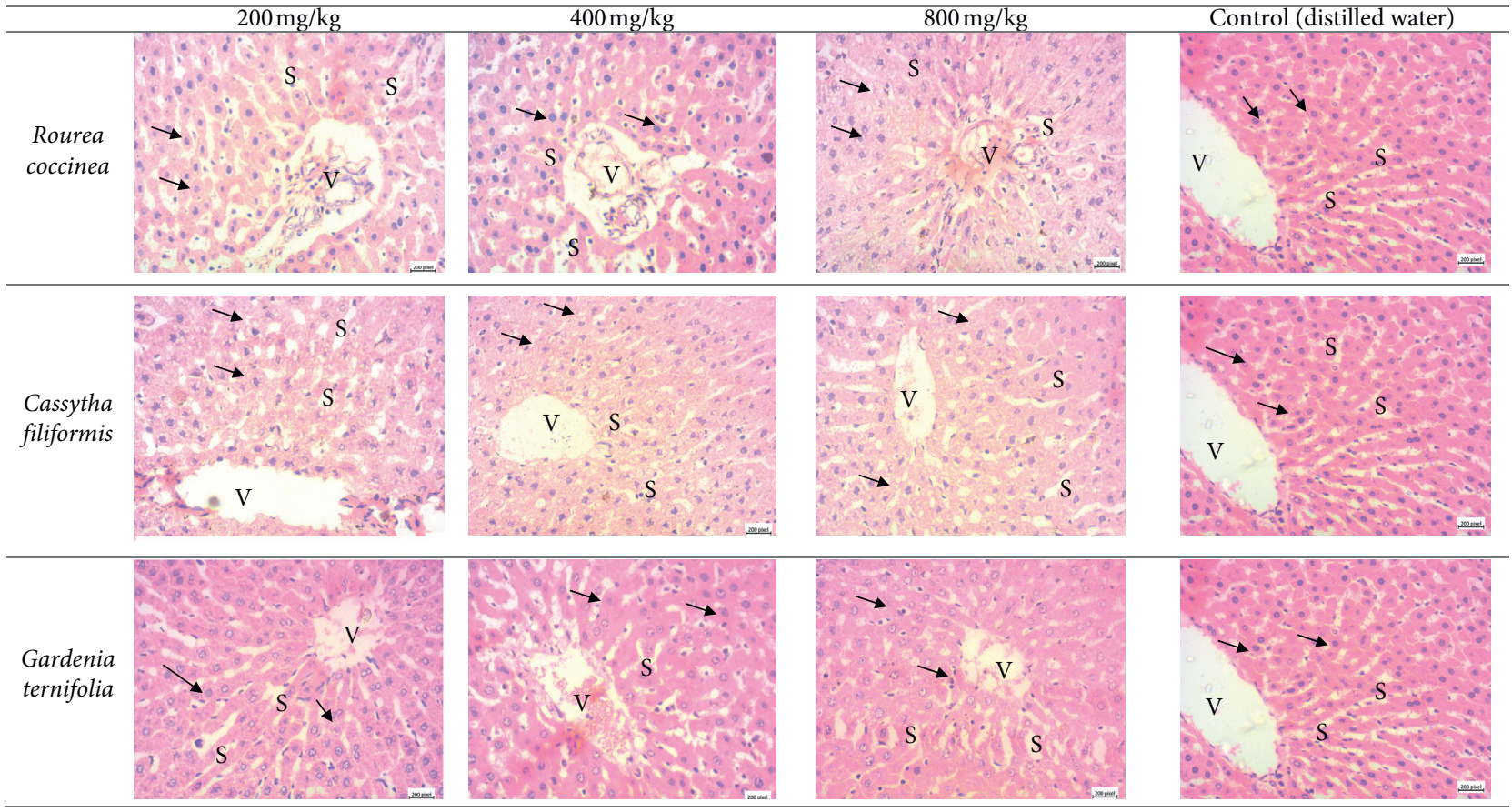

V: centrolobular vein;

S: sinusoids;

$\downarrow$ : hepatocytes

FIGURE 4: Liver histology of treated and untreated rats ( $\times 400$ magnification).

that the renal parenchyma of the treated rats has a typical architecture than that of the control group rats. Glomeruli $(G)$, distal tubes (DT), and collecting ducts (CD) are well identifiable. So, the extracts did not affect the kidney structures.

\section{Discussion}

Medicinal plants and their derivatives are used as an alternative in healthcare by the majority of people in developing countries. Despite its medicinal uses, very few 


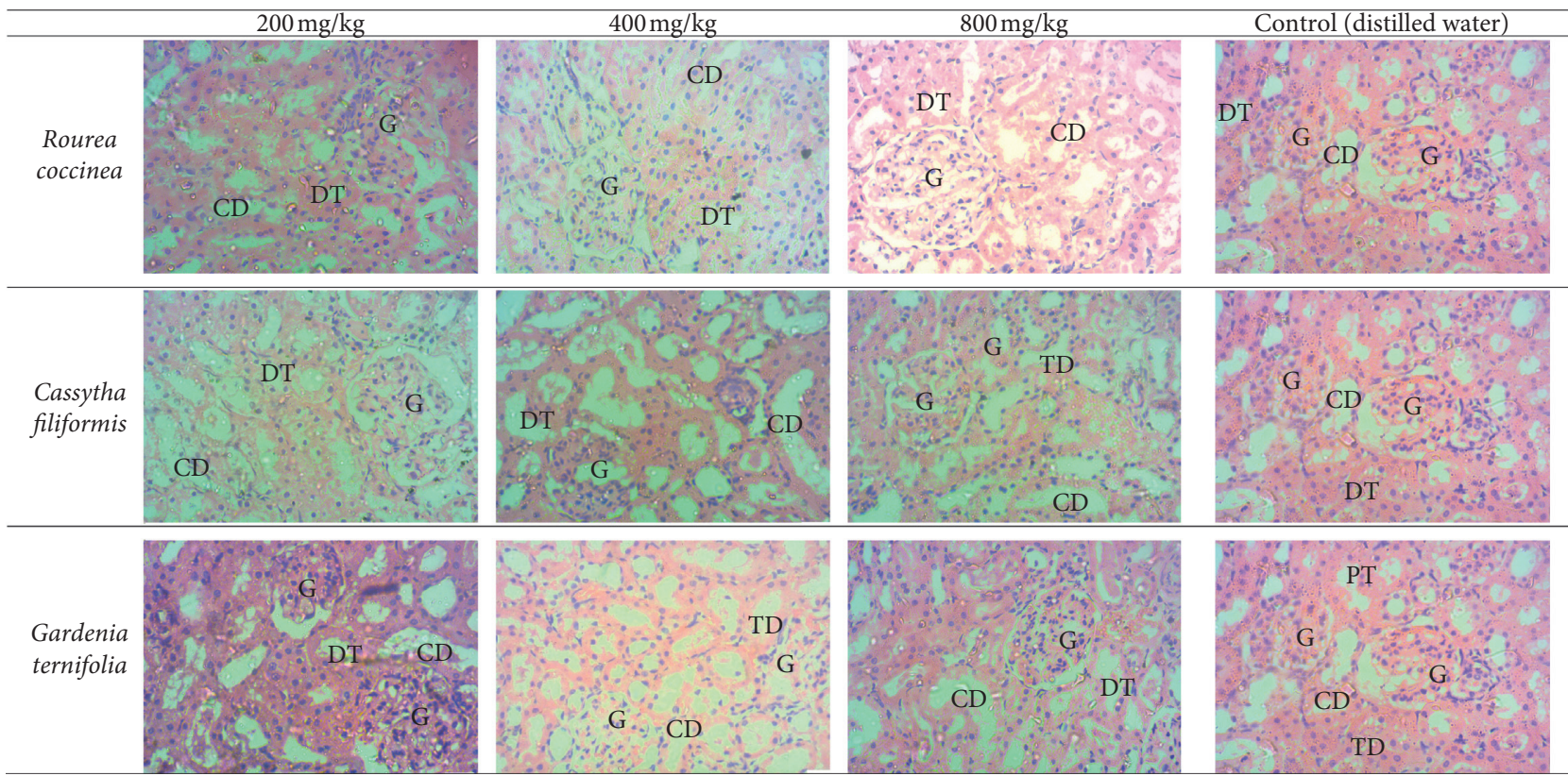

Glomeruli (G); Distal tubes (DT); Collecting ducts (CD)

FIGURE 5: Kidneys histology of treated and untreated rats ( $\times 400$ magnification).

toxicological studies have been conducted on these medicinal plants. The purpose of this study was to evaluate the toxicological effect of $R$. coccinea, $C$. filiformis, and G. ternifolia through larval cytotoxicity and subacute toxicity tests. The cytotoxic effect of the extracts evaluated according to the Artemia salina model was used as a preliminary screening to determine the safety of the plants studied. The results indicated that plants studied at tested concentrations are noncytotoxic to the larvae of Artemia salina. Lagarto Parra et al. [48] demonstrated a good correlation $(r=0.85$; $p<0.05$ ) between this larval cytotoxicity test and toxicological effects on an entire animal. However, such extrapolation is strongly discussed in the literature [49]. To support this data and to explore the safety of the plants studied following daily exposure to repeated doses in the Wistar albino rat, the subacute toxicity test was conducted. The results of this toxicological screening indicated that prolonged exposure of rats to different doses could affect weight growth, biochemical, and hematological parameters. For weight growth of animals during the period of experimentation, a loss of bodyweight should be reported in rats treated with $R$. coccinea extract at high doses (400 and $800 \mathrm{mg} / \mathrm{kg}$ ). These data can be explained by the anorexia observed in these animals during the experiment. Bodyweight change is used as a general indicator of the adverse effects of chemicals on a living organism [6]. Thus, weight loss is correlated with the physiological condition of the animal and can be explained not only by anorexia [50] but also by impaired metabolism in animals [51]. These data indicate that $R$. coccinea may have adverse effects on animal metabolism. In addition, biochemical parameters related to the liver and kidney functions and hematological parameters are generally explored in the study of the toxicity of medicinal plants. It should be noted that ALAT and ASAT are important markers of liver function. Under normal physiological conditions, these markers are present at low concentrations in the serum. The elevation of serum levels of these enzymes, particularly ALAT, is considered a sensitive marker of liver lesions [52, 53]. Similarly, uremia and creatinine are markers of renal function. Any increase in their serum levels reflects a probable tissue damage to the kidneys [54].

Moreover, the hematopoietic system is one of the most sensitive targets for toxic substances [55]. It is an important marker of the physiological and pathological state of humans and animals. Any alteration in erythrocyte parameters is perceived as a potential risk for anemia [51]. In this study, it should be noted that different treatments have some influence on biochemical markers of renal and hepatic functions. Indeed, there was an increase in alanine aminotransferase (ALAT) levels and a significant increase in uremia in animals treated with Cassytha filiformis. This significant increase in uremia was also observed in rats treated with Rourea coccinea at doses of $400 \mathrm{mg} / \mathrm{kg}$ and $800 \mathrm{mg} / \mathrm{kg}$. However, rats treated with Gardenia ternifolia showed a nonsignificant decrease in alanine aminotransferase (ALAT) levels and a significant increase in uremia. In addition, an influence on the hematopoietic system marked by a reduction in the hematocrit level, the number of red blood cells, the mean globular volume, the hemoglobin level, and the mean corpuscular concentration of hemoglobin was also noted for the treatment with $R$. coccinea. These data suggest possible alterations of renal and hepatic functions and risk of anemia. However, histological examination of the kidneys and liver did not reveal any structural alterations of these organs. The confrontation of the data in this study with those in the literature shows variable relationships. Indeed, the studies of Adeyemi et al. [56], on the subacute toxicity of 
the aqueous extract from the leaves of the plant, reported that daily exposure of Wistar rats to this extract by oral route at doses of 40,200 , and $1000 \mathrm{mg} / \mathrm{kg}$ for 30 days had no significant influence on the hematological and biochemical parameters of these animals. However, at an exposure time of 60 days, significant changes in these parameters and bodyweight were reported. Moreover, Wazis et al. [57] reported the toxicity of the ethanolic extract of the leaves of the plant administered by the intraperitoneal route to mice $\left(\mathrm{DL}_{50}=282.24 \mathrm{mg} / \mathrm{kg}\right)$ and Wistar rats $\left(\mathrm{DL}_{50}=1 \mathrm{~g} / \mathrm{kg}\right)$. In addition, in this study, no mortality was recorded for animals treated with this plant. These observations indicate that the use of $R$. coccinea at high doses in traditional medicine requires special attention.

Concerning C. filiformis, a significant increase in uremia and nonsignificant increase in alanine aminotransferase (ALAT) observed in this study suggest a possible impairment of hepatic and renal functions. Similar data were reported in literature. Indeed, Armenia et al. [58] indicated in an acute toxicity study that the ethanolic extract of the plant at doses of 100 and $400 \mathrm{mg} / \mathrm{kg}$ induced hepatic and renal functions in Wistar rats. Similar observations were reported by Yuliandra et al. [59] who showed that the aqueous extract of C. filiformis at doses of $2.5,5$, and $10 \mathrm{mg} / \mathrm{kg}$ exhibited reversible hepatotoxicity indicated by increased alanine aminotransferase (ALAT) enzyme activity. This trend contrasts with data reported by Babayi et al. [36] in Nigeria. These authors, in assessing the subacute toxicity of the watery extract of C. filiformis to Wistar rats, indicated that this type of extract from the plant at doses of 250, 500, and $1000 \mathrm{mg} / \mathrm{kg}$ of live body weight did not influence the biochemical and hematological parameters of the animals or alter vital organs such as the heart, liver, and kidney. This observed difference could be explained by the influence of biotic and edaphic conditions (species, plant physiological status, chemical composition, and soil factors).

Concerning G. ternifolia, the results of this study indicated that no alteration of hematological parameters was observed. However, a possible renal impairment is to be reported in view of the increase in uremia. In the literature, no studies were specifically carried out on repeated dose toxicity of G. ternifolia roots. This study therefore bridged the gap in data on the toxicological profile of the plant. Moreover, two scientific studies of the subacute toxicity of fruit and the acute toxicity of the bark of the roots of G. ternifolia were identified in the literature. Indeed, the studies of Farah et al. [60] showed plant fruit safety at $50 \mathrm{mg} / \mathrm{kg}$ but altered hematological and biochemical parameters at $500 \mathrm{mg} / \mathrm{kg}$. Nureye et al. [17] showed that the bark of $G$. ternifolia roots was safe for mice at a single dose of $2000 \mathrm{mg} / \mathrm{kg}$. Moreover, the alterations of the various biochemical and hematological parameters observed in this study may be related to the alkaloids present in the parts of plants studied [28,61, 62]. Indeed, some plant alkaloids such as pyrrolizidine, tropane, piperidine, and indolizidine are known to have toxicological effects [63].

In view of the above mentioned data, it is necessary to recommend the moderate use of this plant, although no mortality was reported in this study. More in-depth toxicological studies (chronic and subchronic toxicity) are necessary for a better understanding of the toxicological profile of R. coccinea, G. ternifolia, and C. filiformis.

\section{Conclusion}

The purpose of this study was to generate recent data on the toxicological profile of $R$. coccinea leaves, G. ternifolia roots, and C. filiformis whole plant. The results obtained following the larval cytotoxicity model indicated that the studied plants were not cytotoxic. Data from subacute toxicity indicate that the studied plants did not induce any mortality or structural alterations in the liver and kidneys. However, disorders of certain biochemical and hematological parameters were noted in animals treated with $R$. coccinea and C. filiformis at high doses $(400 \mathrm{mg} / \mathrm{kg}$ and $800 \mathrm{mg} / \mathrm{kg})$. These data suggest a moderate use of these medicinal plants in traditional medicine. Furthermore, toxicological studies (chronic and subchronic toxicity) are needed to better understand the toxicological profile of these plants.

\section{Data Availability}

The data used to support the findings of this study are included within the article.

\section{Conflicts of Interest}

The authors declare that there are no conflicts of interest.

\section{Authors' Contributions}

EA and JRK participated in all stages of the production of this article. JMA, JD, and VD provided the scientific direction of the works. TIS, MH, RA, ED, JA, and PA participated in animal experiment. FK and AP participated in biochemical and hematological examinations. All authors participated in reading and editing the manuscript.

\section{Acknowledgments}

The government of Benin through a doctoral grant called the PhD Student 2017-2018 support program of Ministry of Higher Education and Scientific Research provided the financial support. The authors are grateful to them for their support.

\section{References}

[1] OMS, Stratégie de l'OMS Pour la Médecine Traditionnelle Pour 2002-2005, OMS, Geneva, Switzerland, 2002.

[2] H. N. Bayaga, N. M. Guedje, and E. H. Biye, "Approche ethnobotanique et ethnopharmacologique des plantes utilisées dans le traitement traditionnel de l'ulcère de buruli à Akonolinga (Cameroun)," International Journal of Biological and Chemical Sciences, vol. 11, no. 4, pp. 1523-1541, 2017.

[3] J. Klotoé, T. V. Dougnon, J.-M. Ategbo et al., "Ethnopharmacological survey on antihemorrhagic medicinal plants in south of Benin," European Journal of Medicinal Plants, vol. 3, no. 1, pp. 40-51, 2013.

[4] K. Béné, D. Camara, N. Fofie et al., "Etude ethnobotanique des plantes médicales utilisées dans le département de Transua, 
District du Zanzan," Journal of Animal \& Plant Sciences, vol. 27, no. 2, pp. 4230-4250, 2016.

[5] P. Zerbo, J. Millogo-Rasolodimby, and O. G. NacoulmaOuedraogo, "Contribution à la connaissance des plantes médicinales utilisées dans les soins infantiles en pays San, au Burkina Faso," International Journal of Biological Chemical Sciences, vol. 3, no. 1, pp. 262-274, 2007.

[6] J. E. Hilaly, Z. H. Israili, and B. Lyoussi, "Acute and chronic toxicological studies of Ajuga iva in experimental animals," Journal of Ethnopharmacology, vol. 91, no. 1, pp. 43-50, 2004.

[7] A. A. Zeggwagh, Y. Lahlou, and Y. Bousliman, "Enquete sur les aspects toxicologiques de la phytotherapie utilisee par un herboriste à Fes, Maroc," The Pan African Medical Journal, vol. 14, 2013.

[8] A. Akoègninou, W. J. Van Der Burg, and L. J. G. Van Der Maesen, Flore Analytique du Bénin, Backhuys Publishers, Weesp, Netherlands, 2006.

[9] E. Agbodjento, J. R. Klotoé, T. I. Sacramento et al., "Ethnobotanical knowledge of medicinal plants used in the treatment of male infertility in southern Benin," Advances in Traditional Medicine, 2020.

[10] J. R. Klotoé, E. Agbodjento, V. T. Dougnon et al., "Exploration of the chemical potential and antioxidant activity of some plants used in the treatment of male infertility in southern Benin," Journal of Pharmaceutical Research International, vol. 32, no. 4, pp. 1-12, 2020.

[11] S. D. Karou, T. Tchacondo, M. A. Djikpo Tchibozo et al., "Ethnobotanical study of medicinal plants used in the management of diabetes mellitus and hypertension in the central region of Togo," Pharmaceutical Biology, vol. 49, no. 12, pp. 1286-1297, 2011.

[12] E. Tekou, A. P. Mouzou, S. Titrikou, K. Eklu-Gadegbeku, K. Aklikokou, and M. Gbeassor, "Effets de l'extrait semiethanolique des feuilles de Gardenia ternifolia (Rubiaceae), shum et thunn sur le systeme cardiovasculaire du rat wistar," Journal de la Recherche Scientifique de l'Université de Lomé, vol. 14, no. 2, pp. 109-117, 2012.

[13] G. E. Holaly, K. D. Simplice, G. Charlemagne et al., "Étude ethnobotanique des plantes utilisées dans le traitement du diabète dans la médecine traditionnelle de la région Maritime du Togo," The Pan African Medical Journal, vol. 20, p. 437, 2015.

[14] P. T. Mpiana, K. T. N. Ngbolua, D. Tshibangu, P. V. Tsalu, and D. T. Mwanangombo, "Antisickling and radical scavenging activities of anthocyanin extracts from the leaves of Gardenia ternifolia subsp. Jovis-Tonantis (Welw.) Verdc. (Rubiaceae)," Sickle Cell Disease Genetics, Management and Prognosis, pp. 61-77, NOVA, Hauppauge, NY, USA, 2015.

[15] D. Tshibangu, S. Divakar, M. Ramanathan et al., "In vitro screening of the leaf extracts from Gardenia ternifolia (Forest Gardenia) for their anticancer activity," Journal of Complementary and Alternative Medical Research, vol. 1, no. 2, pp. 1-7, 2016.

[16] K. N. Ngbolua, B. L. Mandjo, J. M. Munsebi et al., "Etudes ethnobotanique et écologique des plantes utilisées en médecine traditionnelle dans le District de la Lukunga à Kinshasa (RD Congo)," International Journal of Innovation and Scientific Research, vol. 26, no. 2, pp. 612-633, 2016.

[17] D. Nureye, E. Engidawork, S. Assefa, and T. Nedi, "In vivo antimalarial activity of the $80 \%$ methanolic root bark extract and solvent fractions of Gardenia ternifolia Schumach. \& Thonn. (Rubiaceae) against Plasmodium berghei," Evidencebased Complementary and Alternative Medicine, vol. 2018, Article ID 9217835, 10 pages, 2018.
[18] H. M. Farah, S. M. Hassan, T. H. El Amin, and R. M. E. H. Abdel, "In vitro activity of the aqueous extract of Gardenia ternifolia fruits against Theileria lestoquardi," Journal of Medicinal Plant Research, vol. 6, no. 41, pp. 5447-5451, 2016.

[19] F. B. Magassouba, A. Diallo, M. Kouyaté et al., "Ethnobotanical survey and antibacterial activity of some plants used in Guinean traditional medicine," Journal of Ethnopharmacology, vol. 114, no. 1, pp. 44-53, 2007.

[20] K. Oulare, M. S. Barry, F. Bah et al., "Anti-oxidative activity of fruit extracts of some medicinal plants used against chronic diseases (diabetes, hypertension) in Kankan, Guinea," Journal of Plant Sciences, vol. 3, no. 1-2, pp. 1-5, 2014.

[21] Y. Y. D. Dahiru, "Effect of aqueous leaves extract of Gardenia ternifolia plant on carbon tetrachloride-induced hepatotoxicity in rats," IOSR Journal of Pharmacy and Biological Sciences, vol. 10, no. 6, pp. 73-82, 2015.

[22] M. M. Thiam, “Contribution à l'étude de la valorisation et de la conservation "ex situ" de deux plantes de la pharmacopée traditionnelle sénégalaise: Combretum micrantum et Gardenia ternifolia," Université Cheik Anta Diop de Dakar, Dakar, Senegal, thèse, Doctorat, 2002.

[23] A. Diouf, "Contribution à l'étude chimique d'une plante utilisée au sénégal contre le paludisme "Gardenia ternifolia", Université Cheikh Anta Diop de Dakar, Dakar, Senegal, thèse, Doctorat, 2005.

[24] C. O. Ochieng, J. Ogweno Mid, and P. Okinda Owu, "Antiplasmodial and larvicidal effects of surface exudates of Gardenia ternifolia aerial parts," Research Journal of Pharmacology, vol. 4, no. 2, pp. 45-50, 2010.

[25] O. K. Dada, A. J. Akindele, O. A. Morakinyo, M. O. Sofidiya, and D. Ota, "Hypoglycemic and antioxidant activities of the hydroethanolic leaf extract of Byrsocarpus coccineus Schumach. \& Thonn. (Connaraceae)," Chinese Journal of Natural Medicines, vol. 11, no. 6, pp. 628-637, 2013.

[26] A. J. Akindele and O.O. Adeyemi, "Antipyretic activity of Byrsocarpus coccineus Schum and Thonn. (Connaraceae)," International Journal of Pharmacology, vol. 3, no. 4, pp. 357-361, 2007.

[27] A. J. Akindele and O. O. Adeyemi, "Evaluation of the antidiarrhoeal activity of Byrsocarpus coccineus," Journal of Ethnopharmacology, vol. 108, no. 1, pp. 20-25, 2006.

[28] A. A. Ahmadu, I. N. Akpulu, H. S. Hassan, M. I Sule, and U. U. Pateh, "Preliminary phytochemical and antimicrobial screening of the leaves of Byrsocarpus coccineus Schum \& Thonn. (Connaraceae)," Journal of Pharmacy Bioressource, vol. 3, no. 2, pp. 107-110, 2006.

[29] J. Bero, H. Ganfon, M.-C. Jonville et al., "In vitro antiplasmodial activity of plants used in Benin in traditional medicine to treat malaria," Journal of Ethnopharmacology, vol. 122, no. 3, pp. 439-444, 2009.

[30] E. J. Adjanohoun, V. Adjakidjè, M. R. Ahyi et al., Contribution aux Études Ethnobotanique et Floristique en Republique Populaire du Togo, Agence de Coopération Culturelle et Technique, Paris, France, 1986.

[31] K. Dosseh, T. Kpatcha, Y. Adjrah et al., "Anti-inflammatory effect of Byrsocarpus coccineus Schum. and Thonn. (Connaraceae) root," World Journal of Pharmaceutical Research, vol. 3, no. 3, pp. 3585-3598, 2014.

[32] W. H. Lewis, "The useful plants of west tropical Africa," Economic Botany, vol. 40, no. 2, p. 176, 1986.

[33] A. Hamid and O. O. Aiyelaagbe, "The evaluation of antimicrobial properties and phytoconstituent screening of 
Brysocarpus coccineus leaves grown in south-west Nigeria," Pelagia Research Library, vol. 2, no. 4, pp. 99-105, 2011.

[34] B. Muhammad, A. Mann, M. M. Ndamitso et al., "GC-MS analysis of phytoconstituents and aphrodisiac activity of the root extract of Byrsocarpus coccineus Schum and Thonn," Lapai Journal of Applied and Natural Sciences, vol. 2, no. 1, pp. 48-55, 2017.

[35] Y. Mythili, S. Gajalakshmi, and A. Sathiavelu, "Pharmacological activities of Cassytha filiformis: a review," Asian Journal of Plant Science \& Research, vol. 1, no. 1, pp. 77-83, 2011.

[36] H. M. Babayi, J. J. I. Udeme, J. A. Abalaka et al., "Effect of oral administration of aqueous whole extract of Cassytha filiformis on haematograms and plasma biochemical parameters in rats," Journal of Medical Toxicology, vol. 3, no. 4, pp. 146-151, 2007.

[37] J. Quetin-Leclercq, C. Stevigny, S. Hoet, S. Block, and M.C. Wautier, "Studies on Cassytha filiformis from Benin: isolation, biological activities and quantification of aporphines," in Proceedings of Bioresources Toward Drug Discovery and Development, pp. 81-107, 2004.

[38] M. Sathiavelu and S. Arunachalam, "High performance thin layer chromatography profile of Cassytha filiformis," Asian Pacific Journal of Tropical Biomedicine, vol. 2, no. 3, pp. S1431-S1435, 2012.

[39] T. I. Edewor, S. O. Owa, S. O. Ologan, A. O. Ologan, and F. Akinfemi, "Quantitative determination of the saponin content and GC-MS study of the medicinal plant Cassytha filiformis (Linn.) leaves," Journal of Coastal Life Medicine, vol. 4, no. 2, pp. 154-156, 2016.

[40] A. Swargiary, M. Daimari, and P. Sarma, "Acute and subacute toxicity evaluation of methanolic extract of Hodgsonia heteroclita (Roxb.)," International Journal of Biosciences, vol. 12, no. 6, pp. 488-496, 2008.

[41] OCDE_407, Test No. 407: Repeated Dose 28-Day Oral Toxicity Study in Rodents, OECD, Paris, France, 2008.

[42] OCDE_423, Test No. 423: Acute Oral Toxicity-Acute Toxic Class Method, OECD, Paris, France, 2002.

[43] T. V. Dougnon, H. Bankolé, P. A. Edorh et al., "Cytotoxicity of leaves and fruits of Solanum macrocarpon Linn (Solanaceae) against shrimp larvae (Artemia salina Leach)," Research Journal of Recent Sciences, vol. 2, no. 5, pp. 6-9, 2013.

[44] M. Mousseux, "Test de toxicité sur les larves d'Artemia salina et d'entretien d'un élevage de balanes," DEUST Aquaculture, Centre Universitaire de Nouvelle-Calédonie, Noumea, France, Rapport de stage de deuxième année, 1995.

[45] E. S. Chijioke, A. Oko, U. Osonwa, and E. G. Ofobuike, "In vivo antimalarial screening of ethanolic extract of Cassytha filiformis and its ameliorative effect on haematological and biochemical parameters altered in Plasmodium berghei infected mice," Journal of Biology, Chemistry and Pharmacy, vol. 3, no. 1, pp. 5-15, 2019.

[46] I. I. Ezeigbo and I. U. Asuzu, "Preliminary evaluation of the antihyperglycaemic properties of medicinal plants in Nsukka Area, Enugu State, Nigeria," International Journal of Current Research, vol. 5, pp. 6-8, 2010.

[47] O. Sodipo, F. I. Abdulrahman, T. E. Alemika, and I. A. Gulani, "Chemical composition and biological properties of the petroleum ether extract of Solanum macrocarpum L. (local name: Gorongo)," British Journal of Pharmaceutical Research, vol. 2, no. 2, pp. 108-128, 2012.

[48] A. Lagarto Parra, R. Silva Yhebra, I. Guerra Sardiñas, and L. Iglesias Buelaa, "Comparative study of the assay of Artemia salina $\mathrm{L}$. and the estimate of the medium lethal dose (LD50 value) in mice, to determine oral acute toxicity of plant extracts," Phytomedicine, vol. 8, no. 5, pp. 395-400, 2001.

[49] S. Sánchez-Fortún, F. Sanz, A. Santa-María et al., "Acute sensitivity of three age classes of Artemia salina Larvae to seven chlorinated solvents," Bulletin of Environmental Contamination and Toxicology, vol. 59, no. 3, pp. 445-451, 1997.

[50] A. H. Betti, A. C. Stein, E. Dallegrave et al., "Acute and repeated-doses (28 days) toxicity study of Hypericum polyanthemum Klotzsch ex Reichardt (Guttiferare) in mice," Food and Chemical Toxicology, vol. 50, no. 7, pp. 2349-2355, 2012.

[51] J. T. Mukinda and J. A. Syce, "Acute and chronic toxicity of the aqueous extract of Artemisia afra in rodents," Journal of Ethnopharmacology, vol. 112, no. 1, pp. 138-144, 2007.

[52] D. E. Amacher, "A toxicologist's guide to biomarkers of hepatic response," Human \& Experimental Toxicology, vol. 21, no. 5, pp. 253-262, 2002.

[53] S. K. Ramaiah, "A toxicologist guide to the diagnostic interpretation of hepatic biochemical parameters," Food and Chemical Toxicology, vol. 45, no. 9, pp. 1551-1557, 2007.

[54] Y. Yuliandra, A. Armenia, A. N. Salasa, and F. Ismed, "Uji toksisitas subkronis ekstrak etanol tali putri (Cassytha filiformis L.) terhadap fungsi ginjal tikus," Jurnal Sains Farmasi \& Klinis, vol. 2, no. 1, pp. 54-59, 2015.

[55] P. Manda, O. Manda, M. O. Vangah Manda et al., "Etude des toxicités aigue et subaiguë du remède nature utilise dans le traitement du paludisme," Revue Ivoirienne des Sciences et Technologie, vol. 29, pp. 145-458, 2017.

[56] O. O. Adeyemi, A. Akindele, and K. I. Nwumeh, "Acute and subchronic toxicological assessment of Byrsocarpus coccineus Schum. and Thonn. (Connaraceae) aqueous leaf extract," International Journal of Applied Research in Natural Products, vol. 3, no. 2, pp. 1-11, 2010.

[57] C. H. Wazis, J. A. Anuka, S. Y. Timothy, A. U. Zezi, G. T. Mohammed, and I. M. Hussaini, "Acute toxicity and invivo effects of leaf extracts of Byrsocarpus coccineus Shum \& Thonn in pregnant rat uterus," Journal of Applied Pharmaceutical Science, vol. 2, no. 12, pp. 130-136, 2012.

[58] N. Armenia, D. Gustinanda, G. Nur Salasa, and Y. Yuliandra, "Acute and delayed toxicity study of Cassytha filiformis defatted ethanolic extract," World Journal of Pharmacy and Pharmaceutical Sciences, vol. 4, no. 10, pp. 155-162, 2015.

[59] Y. Yuliandra, A. Armenia, R. Arief, M. H. Jannah, and H. Arifin, "Reversible hepatotoxicity of Cassytha filiformis extract: experimental study on liver function and propofolinduced sleep in mice," Pharmacognosy Journal, vol. 11, no. 1, pp. 69-74, 2019.

[60] H. Farah, H. Khalid, A. Hussein, and H. Osman, "Toxic effect of Gardenia ternifolia fruit on rats," European Journal of Medicinal Plants, vol. 24, no. 1, pp. 1-9, 2018.

[61] K. N. Ngbolua, D. S. T. Tshibangu, P. T. Mpiana et al., "Antisickling and antibacterial activities of some extracts from Gardenia ternifolia subsp. Jovis-tonantis (Welw.) Verdc. (Rubiaceae) and Uapaca heudelotii Baill. (Phyllanthaceae)," Journal of Advances in Medical and Pharmaceutical Sciences, vol. 2, no. 1, pp. 10-19, 2014.

[62] F.-R. Chang, Y. C. Chao, C.-M. Teng, and Y.-C. Wu, "Chemical constituents from Cassytha filiformis II," Journal of Natural Products, vol. 61, no. 7, pp. 863-866, 1998.

[63] K. Z. M. Adibah and M. A. Azzreena, "Plant toxins: alkaloids and their toxicities," GSC Biological and Pharmaceutical Sciences, vol. 6, no. 2, pp. 21-29, 2019. 